\title{
Exploring Women's Identity in Selected Charles Dickens's Works: A re-visitation from a Contemporary African Perspective
}

\author{
Taofiki Koumakpaï
}

Full Professor of British Literature, Department of English Studies, Faculty of Arts and Humanities (F.L.A.S.H.), University of Abomey-Calavi (U.A.C), BENIN

\section{Kossi Joiny Towa-Sello}

Lecturer-Researcher, Department of English Studies, Faculty of Arts and Humanities (F.L.A.S.H.), University of Abomey-Calavi (U.A.C), BENIN, BP: 236Togoudo, (Abomey-Calavi, Rép Bénin) KossiJoinytowasello@gmail.com

\begin{abstract}
The aim of this article is to scrutinize and discuss Charles Dicken's perception of women's identity in British society during the Victorian period through some selected works. This unfolds through a re-visitation from a contemporary African women perspective. The ongoing study has first and foremost highlighted the impacts of industrialization on British women's conditions. The second leg of this paper has consisted in showing how some of the fictional works authored by Charles Dickens have depicted and portrayed the social injustice prevailing in Great Britain during the period under study. Indeed, to achieve its objective, this research paper has lightly drawn on the feminist and new historicist theories while making an attempt to compare Dickens' portrayal of women of the Victorian era to that made of contemporary African women.
\end{abstract}

Keywords: Women's identity, new historicism, feminism, British industrialization

Résumé : Le présent article explore les différentes perceptions relatives à l'identité de la femme telles qu'abordées par Charles Dickens dans certaines de ses ouvres datant du $19^{\text {ème }}$ Siècle. Cela se déroule à travers un réexamen selon l'approche de la femme contemporaine Africaine. Dans son contenu, cette étude met d'abord en exergue les effets de l'industrialisation sur les conditions de la femme Britanniques. Le deuxième pan de cet article a consisté à montrer comment certaines œuvres de fiction de Charles Dickens ont réussi à peindre et décrire l'injustice sociale qui battait son plein en Grande Bretagne au $19^{\text {ème }}$ siècle. Pour atteindre cet objectif, le présent article s'est appuyé sur les théories du féminisme et du nouvel historicisme tout en faisant une analyse comparative du portrait de Charles Dickens de la femme Britannique de cette époque à celle de la femme Africaine contemporaine.

Mots clés: identité de la femme, nouvel historicisme, féminisme, industrialisation britannique.

\section{INTRODUCTION}

The perception of human being by the proponents of social unrest varies according to the position, capacity, quality, epoch and location throughout the world. Therefore, there is an intrinsic linkage between a particular people and the type of environment they live in. That is what Koumakpaï spotted in his George Eliot criticism. He ended by establishing a direct link between her heroines and the moral growth ${ }^{1}$. The $19^{\text {th }}$ century Victorian era was characterized by a fully-fledged development of Industrial Revolution which eventually worsened the working class' living conditions, affecting particularly women. That results in tremendous changes in the various social fields including but not limited to religion, economy, politics, and literature. In this respect Eliot illustrates some of these changes as follows:

For more than fifty years before her birth important change had been taking place in the English countryside, and they were still going on . New methods of farming were improving the use of the

\footnotetext{
${ }^{1}$ Taofiki Koumakpai, The Moral Growth of George Eliot's Heroines: A Critical Study, p. 96 
land, while the enclosure of open fields and commons altered even the appearance of the country. New machines were invented, and goods which used to be made by individual craftsmen in their own village workshops could now be manufactured more quickly and profitably in large factories .Often people from the country moved to towns to work in these factories; the towns themselves grew and spread, creating dreary slum areas. New roads and canals meant that transport and travelling became much easier. ${ }^{2}$

From this assertion, it clearly ensues that there was a discriminatory atmosphere which stands as the peculiar predicament to women's blossoming. This prompted the social novelist to bear George Eliot as name instead of her original one which was Mary Ann Evans ${ }^{3}$. As a matter of fact, that womanoriented disturbance goes from their houses to their workplaces, causing them to lose all traditional opportunities. The main objective in this paper is to highlight how the industrial revolution has impacted on women's identity under Queen Victoria's reign. Beyond that, it opens a window for revisiting African contemporary women compared to their British counterparts during the Victorian period. Eventually it explores to what extent these contemporary African women can contribute to the development of their continent and the world, at large. In other words, this is about how women's contribution could significantly promote and sustain development. In order to deliver the set objective, this paper considers the qualitative method research to carry out a critical investigation, interpretation and criticism of Charles Dickens's novel against the backdrop of two basic literary theories- New Historicism and Feminism.

\section{THEORETICAL FRAMEWORK}

New Historicism is a theory in literary criticism which suggests that literature must be studied and interpreted within the context of both the history of the author and the history of the critic. This theory arose in the 1980s, under the leadership of Stephen Greenblatt ${ }^{4}$ who appears to be its main proponent. It gained ground and became quite popular in the 1990s. Critics using this literary theory view a work along with any other things that may have inspired it; this includes the author's life and how it is ingrained in the fictional text under study. New Historicism evaluates how the work is influenced by the epoch during which it has been written. It also examines the author's social sphere, culture, class, and the writer's psychological background. With those characteristics, this theory can sufficiently give adequate room to discussing and making critical pronouncement regarding women identity. Viewed in line with the ongoing re-visitation of Charles Dickens' novel, new historicism helps pinpointing how British culture, society, class structure and politics of the epoch might have shaped the author's beliefs. As pointed out earlier, the critique of Charles Dickens is intrinsically linked to other socio-political thoughts.

Defining New Historicism without feminism in the context of the $19^{\text {th }}$ century makes it incomplete. It is quite inadequate to attempt to interpret the new historicist dimension in Charles Dickens's works and history without considering feminism. Furthermore, investigating the Nineteenth century women's identity without referring to feminist theory would seem barren. Feminist criticism has emerged before the late 1960s, because the first uses of that pattern dates far back to the $1880 \mathrm{~s}^{5}$. However, during the so called Second Wave of feminist criticism, the stereotypical and often misogynist portrayal of female characters in male literary works such as the novel Dracula too belongs, had become the spotlight of analyses. Humm (1994:8) contends that two major achievements of criticism were that they exposed the gender stereotyping, and offered possible explanations for the continuing stereotyping. He further describes the first stage [of feminist criticism], as often characterized as the break with the fathers, [as] a series of revisionary readings of what Ellmann calls

\footnotetext{
${ }^{22}$ Eliot George, Silas Marner, p. Vii

${ }^{3}$ Eliot George, The Mill on the Floss, Preface
}

${ }^{4}$ Stephen Jay Greenblatt (born November 7, 1943) is an American literary critic, theorist, scholar, and Pulitzer Prize winning author. He is John Cogan University Professor of the Humanities at Harvard University. He is the editor of the Norton Shakespeare (2015) and a contributor to the Norton Anthology of English Literature .Greenblatt is regarded by many as one of the founders of New Historicism, a set of critical practices that he often refers to as "cultural poetics"; his works have been influential since the early 1980s when he introduced the term On https://en.wikipedia.org/wiki/Stephen_Greenblatton

${ }_{55}^{55}$ Maggie Humm, A Reader's Guide to Contemporary Feminist Literary Criticism, p.1. 
'phallic' writing (1994:9), and the critics as fundamentalists because they try to find fundamental and universal explanations for the subordination of women in literary representations ${ }^{6}$.

\section{Literature RevieW AND CONCEPTUAL Clarification}

Behind this beautiful picture ${ }^{7}$ of England by Charles Dickens, as he asserts in his Hard Times: Time went on in Coketown like its own machinery: so much power material wrought out up, so much fuel consumed, so many powers worn out, so much money made ${ }^{8}$, the Industrial Revolution hide the social unrest which constitutes the daily routine for many writers including Gaskell, George Eliot and Charles Dickens. They endeavor to express the spirit of the age with all the resources of thoughts, feeling and thought. They reveal their responses to their then society schisms and its impacts on them. Gaskell addresses, in her works, the conflict between social classes under the British external imperialism. Mary Barton and North and south ${ }^{9}$, rather deals with society and women conditions, while the relationship between men and women was the cornerstone of the narrative in Wives and Daughters and Cranford. As for Charles Dickens, he also depicts some social illnesses and points out his concept of women of the $19^{\text {th }}$ Century through novels such as Great Expectations, Oliver Twist and Hard times. Contrary Gaskell, Charles Dickens, as a social novelist, has put emphasis on women's proper identity, making strong advocacy in favor of education and Facts teaching as follows: Now, what I want is, Fact, Teach these boys and girls nothing but Facts. Facts alone are wanted in life. Plant nothing else ${ }^{10}$, knowing that child care is a matter of both women and men. But for women's identity, priority is given to them to discharge that duty of paramount importance. This aspect being covered, the next segment under this section provides clarification about some key concepts which enable a better understanding of the ongoing analysis.

The identity of a person or place is the characteristics that distinguish him/her/it from others. It is defined, not in fixed terms but in relation to other objects of proximity. Identity is the state of being the same individuality; personality; who or what a person or a thing is, according to the Chambers Dictionary. For Aristote, l'identité est une unité, ou unité d'une multiplicité d'êtres, ou, enfin, unité d'un seul, traité comme multiple ${ }^{10}$. Women's identity, however, has always been related to that of men. St Thomas defines woman as "imperfect man" by saying: simply means that as woman is less continent than man she should be under man's power ${ }^{I 2}$. Aristotle views and characterises women as an embodiment of a certain "lack of qualities" vis-à-vis man. Further, the Holy Scriptures assign a secondary and subsidiary position to women through the character of Eva — created out of Adam's rib. Even the ancient Indian scripture Manusmriti proclaims women as physically, intellectually and morally inferior to men. Hence, conventionally women are always defined in relation to men, ". . . she is the incidental, the inessential as opposed to the essential" (Beauvoir xvi). Women have always acquired peripheral space at the circle of domesticity where men are poised at the centre. It is against the backdrop of these notions that this paper attempts to study the portrayal of women in Charles Dickens's selected novels. The $19^{\text {th }}$ century's women had no such choices, they were involved in everything and it is in this vein that Keating claims: For the first time in her life Louisa had come into one of the dwellings of the Coketown Hand; for the first in her life she was face to face with anything like individuality in connexion with them ${ }^{13}$.

The quotation above is evidence testifying the change that woman's identity has gone through during Queen Victoria reign. Besides, Charles Dickens' mother has paid her husband's debt when he was arrested. The majority were living in a condition almost similar to/ or little better than that of slavery undergone in Africa and America during slavery Era. They had no other choice than obeying men because in most cases men hold all the resources including the women's means of sustenance and livelihood. That is why, while discussing women issue, Dickens writes: like most Victorians, Charles Dickens believed that a woman should be 'the angel of the house', devoting her life to housekeeping

\footnotetext{
${ }^{6}$ Ibid, p. 21.

${ }^{7}$ Taofiki Koumakpai..........................

${ }^{8}$ Charles Dickens, Hard Times, p.93.

${ }^{9}$ Kossi Joiny TOWA-SELLO, «The working class as depicted in $19^{\text {th }}$ Century In Mary Barton and North and South», University of Abomey-Calavi, 2011

${ }^{10}$ Jacqueline Russ, Dictionnaire de Philosophie (Mémo Références), p. 132.
} 
and child rearing ${ }^{11}$. Here only wealthy widows or spinsters are exceptionally lucky and are not member of the upper class, that is why Gaskell asserts that: None of the women belong to the upper classes $^{12}$ In the way those women many opportunities and it is in this light that Keating asserts: More and more women were coming out of their homes into society ${ }^{13}$.

....... A woman who announces her intention to remain single for life would attract social disapproval and pity because her life would be just like that of a snake which passed on a hill without leaving a mark. She could neither have child nor cohabitate with a man: the social penalties of such a lonely life are simply too high. In Hard Times, Charles Dickens tries throughout to lay a special emphasis on women education since in the Victorian area there has been no clear definition about women's education and place in the society. For Dickens, what a woman is depends on her name because the name one bears impact positively or negatively on her life in the society. By saying Sissy is not a name, don't call yourself Sissy. Call yourself Cecilia ${ }^{14}$ through one his characters, namely Gradgrind, Dickens shows how important naming is in human being's life, and more importantly, women should not accept any given name. The nineteenth Century era was a period of male domination over their female counterparts; a period when women were relegated to the lowest social rank, subjugated to endure and put up with everything men desire from them. Queen Victoria's reign coincided with an epoch when men did not show much consideration towards women. It is a period similar to the one which has prevailed in Africa, when women were banned to voice their mind because they were seen as unable beings who cannot contribute anything to the advancement and development of the society. It was therefore, no use associating them to any decision-making process. In such a male-dominated environment, women's favourite places are elsewhere as Koussouhon and Dossoumou (2015:132) paint in their move to re-define and re-present African woman's identity and personality:

The poor depiction and characterization of African women tally discriminatory comments such as: the woman is like a lifeless piece of property or thing that can be treated like lifeless object; the woman is senseless and incapable of logical reasoning, and as such, cannot partake in decision-making processes at home and in society at large; the woman should neither be seen, nor heard; the place of the woman in society is behind the burning firewood, the cooking pot, and ultimately in the bedroom.

The quotation above is an evidence of the fact that the situation of the British women in $19^{\text {th }}$ was not far away from that of their contemporary African counterparts until recently. On the other side Dickens portrays women's identity in such condition but he does not find solution that can help revamp that poor depiction through his fiction. Rather, he is viewed by Miriam Margolyes as women abuser:

Dickens met Maria again when she was middle-, toothless, fat, old and ugly (her own words). And he ran a mile, taking his revenge in fiction with a depiction of her as the "silly, spoiled" Flora Finching in Little Dorrit. His eye was on slimmer, younger models, whom he treated badly as well. Margolyes describes his behaviour towards young mistress Ellen Terner as that of "an abuser". ${ }^{15}$

Contrary to the situation experienced by the then Victorian era women, contemporary African women are undergoing true changes in their treatment, may it be through their depiction and portrayal in fiction or in real societal environment. Irrespective of the gaps and discrepancies that could be noticed here and there, contemporary African women are more and more coming out of the fray by being more and more educated, empowered, capacitated and emancipated. Nowadays, they have many forums to voice their thinking, feeling and perception in society. Many African women occupy nowadays top-level positions in the public and private administrations. Moreover, they have, in some countries, succeeded in obtaining quota when it comes to their representativeness at political position

\footnotetext{
${ }^{11} \mathrm{http}: / /$ www.dickens-and-london.com/Women.htm

${ }^{12}$ Elizabeth Gaskell, North and South, p. Vi

${ }^{13}$ Anthony Toyne, An English-Reader's History of England, p. 325

${ }^{14}$ Charles Dickens, Hard Times, p. 11.

${ }^{15}$ http://www.telegraph.co.uk/books/authors/charles-dickens-was-an-abuser-of-women-says-miriam-margolyes/
} 
level. Many African Presidents still do not side-line them while forming their cabinet. Many African female writers like Flora Nwapa, Ama Atta Aïdoo, Buchi Emecheta, Chimamanda Ngozie, Kaine Agary, Nadine Gordimer, Ngozie Chuma-Udeh, and so on and so forth, have come out to champion their peers' causes through the depiction of their identity and personality through fiction. Modern African women are therefore fully socially, politically, intellectually and economically skilled, empowered, capacitated, and are changing their previous subjugation and oppression by men. A vivid illustration of that effective empowerment is expressed through this Fon ${ }^{16}$ proverb which states: $A$ man sees a snake and a woman has killed it. What matters, is the death of the reptile ${ }^{17}$. In other words, the most important aspect of this is that the snake is killed; irrespective of who does kill it, it is dead and there is no more danger around.

\section{IMPACTS OF INDUSTRIAL REVOLUTION ON VICTORIAN WOMEN'S IDENTITY}

Before the industrialization advent in Great Britain, women's identity was obviously noticed in three main domains such as family, society and economic spheres. On the family ground, women play an important role in keeping the house, taking good care of children and husband, ensuring the preservation of moral values and moors within the household and especially for girls. At society level, women identity was upgraded and valued through their names and achievements. Women were respected or considered because they were not at all or less involved in social scourges such as crimes commission, prostitution, child trafficking, weapons and ammunitions trafficking, armed robberies, piracies, gangsterism and any other social cankers. At economic sphere level, women have been taking great part in many activities in order to provide their assistance for the welfare of their family, and society at large. Some of these activities have to do with seamstress, agriculture, trade, housemaid servant, weaving loom to list only a few. All those occupations were reserved to women. They were proud of those occupations because they allow them to showcase their knowhow, knowledge, identity and feelings. There was no such an official political movement to which they belong. In other words political affairs were not their concerns. Great Britain was known as the cradle of industrial revolution in Europe in the mid of the $18^{\text {th }}$ Century. Therefore, England was where the first land which allowed the germination and sprouting of industrial revolution From there it spreads all over Europe and reaches America, bringing about many changes along the way covering many sectors. This paper casts a specific look on its economic, social and political knock-on-effects on women.

\subsection{Economic Impacts of Industrial Revolution on Victorian Women}

In the field of economy, the introduction of the industry was identified as a necessity for the progress of human and the economic growth during the Victorian era. It also is driving engine of any social and economic development the achievement of which calls for some sacrifices of manifold worth mentioning. Among them range those which occur within the working class. Working women have been victim of gender-based discrimination. For instance, for the same job performed, female labor was remunerated at lower salary. The worst in the working place was that their working hour or time was longer than men's one. In other words they do not share and enjoy the same rights with men, as a result they have in many occasions failed to achieve their goals and fulfill their duties as mothers, wives and house maids, losing thereby their former personality and identity. Besides, the Poor Law of 1834 has come as the final blow. That legal instrument is a system of laws introduced in England and the rest of Britain to provide public reliefs and assistance to the have-nots. Those include the widows, patients, disabled and unemployed who, by virtue of the new legal provision shall be hired as laborforce. This Legal provision re-inforces the labour executives to inflict crual, inhuman, degrading and humiliating treatments on the poor working class poor including the women. In spite of the prosperity that has emerged within the middle class as a result of capitalism the industrial revolution period was equally characterized by the spread of abject poverty suffered by the majority of the British citizens. Though industrialization has induced new sources of income generation and employments, it has had serious social consequences including rural depopulation in favor of the growing urbanization along with the competition for survival in that nascent capitalistic society.

\footnotetext{
${ }^{16}$ Fon is one of the main local languages spoken in Benin.

${ }^{17}$ Sounou mon dan bo yonnu xu, dan vè kù Translation ours
} 
Moreover, another aspect of the situation in the field of economy is the high desertion rate as the overall labor force, both male and female who had contracted jobs have dropped their employments due to time table constraints. As a matter of fact, women also need time to fulfill their family responsibilities and duties as mother and wives. As industrial time unfolds, the time needed for catering for the family suffer and ended up drastically reduced. Many among the hardworking women who were clung to their families had to drop their discriminating daily jobs and employments for the benefit of their families as those two kinds of responsibilities seem not to converge. Having lost female laborers, the employers had to bear the brunt by recruiting about two men in order to get the result they previously had from one lady, paying subsequently double female salaries for one male laborer. The machinery has also taken over in many companies or factories where women are poorly remunerated at almost half of men's salary for the same amount of effort, time and result. Industrialization has had economic impacts on women but also changed their social life.

\subsection{Social Impacts of Industrial Revolution on Victorian Women}

In order to be at the height of, and commensurate with the various changes induced by industrialization, working class women had to indulge in prostitution and criminal activities for their survival. But it should be recognized that not all women were behaving as rascal with devious, destructive and twisted mindset. In this vein Dickens considers two kinds of women: the rascal fallen and the dove angels who differ based on their educational backgrounds as he advocates in Hard Times. In that respect, he portrays Rachael as simplistic, honest and lovely lady showing true love for Stephen Blackpool for whom she represents his domestic happiness and moral purity. As regard the rascal fallen women with twisted mind, those are the ladies who have lost total control of their lives because as a result of abject poverty and harsh living conditions imposed by the industrial revolution. Since the British society, during the Victorian era, seems to definitely sideline and marginalize women despite their power and authority, the latter have resorted to confine themselves into domesticity. Dickens's characterization of Mrs. Joe Gargery and Molly in Great Expectations, for instance, as victims of exploitation-oriented society is expressive. These characters notice have realized that their social identity is down-sized and underrated in the society they belong to, while their traditional role was altered. It is in that respect that Dickens pinpoints Mrs. Joe Gargery and Molly as destructive ladies upon whom emphasis should be laid as regards the importance of Victorian patriarchy and domesticity. In fact, Mrs. Joe Gargery physically challenges her husband Joe and this depicts how women are fed up and seeking their liberation and freedom from the Victorian bondage. She does not care to embody whatever harmful identity which could be ascribed to her. In fact, she dislikes motherhood and housewifery because for her these two roles as less important. That is what has ended up earning her the punishment she received for deliberately stepping aside her prescribed role as wife and mother. Moreover, still in Great Expectations, Dickens reinforces how women's dictatorship and violence have become the daily routine in the households as a result of industrialization. His character Georgiana known as Mrs. Joe perfectly depicts that as the follow:

By this time, my sister was quite desperate, so she pounced on Joe, and, taking him by the two whiskers, knocked his head for a little while against the wall behind him: while I sat in the corner, looking guiltily on. 'Now, perhaps you'll mention what's the matter,' said my sister, out of breath, 'you staring great stuck pig.' Joe looked at her in a helpless way; then took a helpless bite, and looked at me again. 'You know, Pip,' said Joe, solemnly, ${ }^{18}$

This is a striking evidence of women's resentment as a result of the hardships, injustice and discrimination they were undergoing during the industrial revolution period. In the quotation above, Mrs. Joe claims her identity. The point here is that they have ended up being simply replaced by masculine labor and machines at workplace. In opposition to this, their reaction has not delayed. In their move to revenge and retaliate against their abject poverty they have preferred to indulge in social cankers such as prostitution, criminal activities, corruption and armed robberies and theft which smeared their identity. They are no longer women of virtue but criminal, corrupt, prostitute and thieves. Not only Dickens does portray Mrs. Joe as a fallen woman, but he also depicts Mrs. Stephen Blackpool in Hard Times as: another character who assumes a masculine role. Mrs. Stephen Blackpool lacks sign of femininity, she is depicted as ...A disabled, drunken creature. . . A creature so foul to look at, in her tatters, stains and splashes, but so much fouler than that in her moral

${ }^{18}$ Charles Dickens, Great Expectations, p.11. 
infamy. "19 Dickens introduces her as a creature and drunkard, two terms that nineteenth century women do not deserve.

Another aspect addressed by Dickens in his fiction is that of the fallen women who operate as prostitute. In Oliver Twist, this social canker is portrayed through the character of Nancy who belongs to Fagin's criminal gang. As a member of the syndicate, Nancy is bound to commit crime and prostitution in order to meet her economic needs. On the other side of Dickens's Fallen women, are characters portrayed as "Angel in the house".

Apart from the society canker bearers, there also are other women who have been depicted as having received good and genuine education. In Hard Time, Gradgrind's daughter, later known as Bounderby's wife is disorganized by her education which does not tally her cultural background. Louisa is regarded as by her kinsmen as somebody who is alienated and disconnected from her people. But she unexpectedly confesses that her father's educational system has rather deprived her childhood of happiness. It is worth recalling that women education in the $19^{\text {th }}$ Century was tailored on the basis of dictatorship and subjugation because women must obey and agree whatever the situation, in line with Dickens claim: To hear is to obey ${ }^{20}$. As a matter of the fact the "Angel in the house" has been recurrently portrayed in most of the 19th Century writings. Among those authors ranges Dickens through his focalization, thematization and characterization. In Great Expectations, Biddy is one of the most appreciated characters created by Dickens as a lady managing very well her domestic life ${ }^{21}$.

\subsection{Political Effects of the Industrialization on Victorian Women}

In the early period of the19th Century, Victorian women were much involved in politics because they are supported by their husbands' families and in some cases by their in-laws. The British's industrialization era has come to open women's eyes and mindset as claimed:

Now women wanted the same pay as men for equal work. They wanted society to recognize the development they had made. They wanted complete emancipation and, above all, the vote. The demand for emancipation and the right to vote at elections was made for all women by Emmeline Pankhurst and her two daughters Christabel and Sylvia ${ }^{22}$

In actual fact, their predominant sphere of responsibilities is the household as it was widely advocated through the popular concept of "pater familias" which means that the husband is the head of the household and moral leader of the family; he has strongly ingrained the British culture. The true role of a wife is first and foremost to love, honour and obey her husband, in compliance with wedding pledge statement. A married woman's place in the family hierarchy comes second after her husband. But rather than being underrated or regarded as unimportant, the duties discharged by a wife in a household in terms of catering for the husband and looking after children cannot be neglected at all. Her presence ensures the physical, mental, psychological, economic stability of the family, thereby filling a crucial gap or vacuum that could have destabilised the house.

However, the advent of industrial revolution has brought about a series of changes in different spheres of life. With the new lifestyle induced by industrialization, women have opened their eyes and realized that they have lost part of their identity as a result of the victimization, discrimination and injustice they have been undergoing. So, a study of the industrial revolution throughout its historical literature makes realize the reasons behind women's movement with special emphasis on advocacy for gender equity, the establishment of women's organizations and the rise of a new generation of female artists, photographers, and professionals. Those changes have resulted in social paradigms shift and transformed the previous patriarchal tradition prevailing in the societal structure across the globe.

Followed closely by the outbreak of World War I, these social paradigms shifts, which have been set in motion at the early moments of the $19^{\text {th }}$ Century, have further developed because women have been propelled onto the job market as labour-force, exposed henceforth to the same situations in a

\footnotetext{
${ }^{19}$ Charles Dickens, Hard Times, p.72.

${ }^{20}$ Dickens Charles, Hard Time p. 202.

${ }^{21}$ Dickens, Charles. Great Expectations, p.11

${ }^{22}$ Anthony Toyne, An English-Reader's History of England, p. 327
} 
previously male-dominated professional and political environment. The end of the nineteenth century coincided with women's struggle for universal suffrage and political equity in England and the United States. That period marked the beginning of women's involvement in politics.

\section{CONTEMPORARY AFRICAN WOMEN'S ACHIEVEMENTS THROUGH THEIR INVOLVEMENT IN Politics}

During Queen Victoria's reign in $19^{\text {th }}$ Century the debate on women empowerment was topical because the perception according to which women are inferior to men was henceforth outdated. That is why Dickens advocates for the restructuring of the educational system as for him, no development is possible without education. As Rodney puts it:

Education is crucial in any type of society for the preservation of the lives of its members and the maintenance of the social structure. Under certain circumstances, education also promotes social change. The greater portion of that education is informal, being acquired by the young from the example and behaviour of elders in the society. ${ }^{23}$

This shows how it is urgent and imperious for policymakers to view education as the political tool that must stimulate social change. Besides Dr. Gibson, in Gaskell's Wives and Daughters advocates for an affirmative action policy which puts a special emphasis on girls' education as that could significantly contribute to instill social change in the $19^{\text {th }}$ Century society ${ }^{24}$.

Dickens ranges among the19th Century writers who have strongly made serious advocacy in favor of education. In his Hard Times, he argues that the education he refers to is not a synonymous of a simple classroom teaching or instruction. He highlights the kind of his education type is the one whereby one learns all lifelong and in which women harvest positive impact through a reconsideration of their identity. The opening of Hard Times shocks the reader because of the tough education given to those girls and which rids them of any feeling of selfishness.

There are striking genetic and physiological differences between men and women though women can do almost all what men can perform as activity. Nowadays, in Africa policymakers have designed the appropriate typology of education needed by women. This education provides girls and women with the capacities, competences and skills they are required on the job market. With the education level, knowledge and know-how, they can easily compete and challenge men at some technical positions. They are, at some instances, more equipped and empowered than men. Normally these intellectual, technical and professional capacitation and empowerment are to help women be autonomous so as to assist and help their men and husband. At time the same education serves as breeding ground for the development of certain social cankers among women. Education has turned some women into serious social rascal. Some of them deliberately chose not to marry and remain childless all their life though they are not physiologically challenged or barren. Dickens, through one of his characters, namely Rodney, thinks that the way education designed and established in Africa by Europeans is not appropriate. Moreover, he pursues criticizing that: The colonialists in Africa occasionally paid lipservice to women's education and emancipation, but objectively there was deterioration in the status of women owing to colonial rule. ${ }^{25}$ For education to significantly and deeply change women's life as a whole, in Africa other parameters should be added to the current component of the taught curricula. In this vein, Conrad asserts:

Change doesn't just happen; often it is planned. A strong current thought during the early Industrial revolution viewed industrialisation as a beneficial process of organic development and progress. Still assuming that industrialisation increases production and income, contemporary economists seek to create in third World ("developing") countries a process like the one that first occurred spontaneously in eighteen-century Great Britain. ${ }^{26}$

Flowing along with Conrad, I do believe that for education to genuinely yield the expected fruits and meet the great expectations and hope nurtured by and for African people, it must be first and foremost

\footnotetext{
${ }^{23}$ Walter Rodney, How Europe Underdeveloped Africa, p. 290

${ }^{2424}$ Elizabeth Gaskell, Wives and Daughters, P. 19.

${ }^{25}$ Rodney Walter, How Europe Underdeveloped Africa, p. 274.

${ }^{26}$ Conrad Philip Kottak , Anthropology The Exploration of Human Diversity, p 411.
} 
well designed and planned. It should cater for the real needs expressed by the beneficiaries. It shall no longer be education for the sake of education; just theoretical education. Mathematics or geometry should not be taught where the real needs of the population are more about capacities building in agriculture, animal husbandry, fishing and aquaculture. Economics should not be taught where the tangible needs existing on ground is about addressing plants protection and post-harvest losses. Education will not induce the expected social changes unless it tallies the beneficiary population's needs. Contemporary African women must adapt their formal education to the needs expressed by their fellow compatriots in order not to end up irrelevant and useless. For contemporary African women to be useful for their society, they must be open-minded and prepared to help not only their peers, but also their husbands at home following the example of Dickens' father who has been significantly assisted and supported by his wife when he was in detention. In recognition to women for this legacy of his mother Dickens has assisted many female writers to publish their novel. But nowadays, many women both in African and non-African contexts have been asserting their selfdefence and autonomy to the extent of determining their own careers without men's support at all. As such Association and interests groups through Non-governmental and governmental organizations are established here and there to champion women's causes and defend children, girls and women's rights. Some are specialized in women's educational rights defence while others rather cater for girls' sexual health reproduction's rights by fighting against any kind of gender-based violence against women including sex mutilation which sill is affecting thousands of girls in some regions of this $21^{\text {st }}$ Century world. Many African intellectual women are supportive of feminist theories while others express their preference for womanist move, in support of a balanced development. But obviously, contemporary African women are so empowered and capacitated that they are no longer relegated to the secondary roles of minor importance in the society as it used to be in the past. Both in fictional and real-life situations, contemporary African women's mind-set have significantly changed. Their portrayal, depiction and characterization by female and male fiction writers have positively evolved to come to the stage of redefinition and re-presentation of their identity and personality. From the bottom and poor characters, they are gradually coming to the forefront of actions performance. Many African female writers are gradually deconstructing patriarchy which has served as the backbone of the social schisms that have strengthened African women's plights and predicaments. This $21^{\text {st }}$ Century in the era of self-fulfilment, self-assertion, empowerment and capacitation for African women who are henceforth psychologically and morally prepared to face any situation affecting their identity as a whole. . In spite of all that progress achieved so far, Africa women still come across some hindrances which prevent them from delivering more results. Among those obstacles range the sociocultural constraints and stereotypes which definitely call for concrete and vigorous actions for the Africanisation of women's awareness creation and education, as a whole. As Conrad Phillip Kottak claims: Studying people directly at the local level, ethnogrophers have a unique view of how national and international planning and aid affect the intended beneficiaries ${ }^{27}$. Conrad directly or indirectly advocates for an adaptation of the education to African context and realities. Authorities in charge of International Organizations recognize that many things have been done for women social development as the Chair of the UN Economic Commission for Africa's Committee on Women and Development claims: We are all aware that despite achievements and progress made, African women face major challenges and obstacles ${ }^{28}$.

On July 11 2003, the African Union adopted the Protocol on the Rights of Women in Africa, a supplementary protocol to the African Charter on Human and Peoples' Rights, which was adopted in 1981. The Protocol, which fills a major gap in the regional human rights system (Amnesty International, 2005), calls for the protection of the rights of women in reproductive health, violence against women, elimination of all forms of harmful traditional practices (including early marriage and female genital mutilation, equal right to education and training). ${ }^{29}$

Of course, it is a matter of common knowledge that African policy-makers currently fight for passing laws and bylaws on women's main concerns for their social welfare. But most of the time it is to

\footnotetext{
${ }^{27}$ Conrad Philip Kottak, Anthropology The Exploration of Human Diversity, p 413.

${ }^{28} \mathrm{http} / / / \mathrm{www} . u n . o r g / a f r i c a r e n e w a l / m a g a z i n e / j u l y-2005 /$ african-women-battle-equality

29 http://www.afdb.org/fileadmin/uploads/afdb/Documents/Knowledge/25040341-FR-DRAFT-DEJENE.9-1507DOC.PDF
} 
avoid being cut off some financial assistance or aid. An inventory of the existing laws and bylaws either passed or domesticated by African governments reveals that most of those legal instruments are not effectively enforced in favor of women who, at this stage of development deserve more positive social treatments. As a matter of fact, though there is progress made here and there, there are still some pockets of fierce resistance among African countries where women continue to suffer from discrimination, stigma, gender-based violence, illiteracy, unequal access to social amenities, just to mention a few. As such mauch remain to be done in order to fully sustain women's entire societal blossoming in Africa and, at large, in the world.

\section{SUMMARY AND CONCLUSION}

This article was premised on the exploration of women's identity in some Charles Dickens' selected works from a contemporary African perspective. This re-visitation of Dickens' portrayal, depiction of the treatments inflicted to British Women during the Victorian era through narratological devices like characterization and thematization as a result of industrial revolution have been thoroughly explored. Industrialization has, indeed brought about the emancipation and liberation of British women who have henceforth asserted their capacities, skills and competences in many socioeconomic sectors. Besides, this era has opened women's eyes in terms of empowerment and emancipation, involvement in politics and participation the nation's economy through their various income generating activities despite their victimization and social discrimination which finally earned them their abandonment of their employments and jobs. This social situation has not failed to generate its drastic consequences such as prostitution, women's involvement in criminal activities and social cankers.

On the other side, a comparison with the situation being experienced by contemporary African women has revealed that the $21^{\text {st }}$ Century women are more empowered, capacitated, skilled and less stigmatized and discriminated. Furthermore, the exploration has demonstrated how contemporary African women have being able to, and still continue to reshape their identity both through fictional and non-fictional works. On the legal ground, this paper has come up with the conclusion that though many African countries has succeeded in passing pro-women legal instruments, there still is much to do about those nations which still beat their wings and lag behind to catch up the women's fully geared blossoming train. This should be done through ffective and efficient educational curricula and training programmes that really commensurate, tally and meet the beneficiaries' needs. That calls for re-orienting innovations regarding the application of official development assistance in order to avoid wasting and squandering resources on unnecessary projects.

Women around the world often face daunting social, economic and political challenges. For democratic governments to deliver to their constituents, they must abide by the principle of representativeness. In other words, even if one cannot proclaim equal representativity, at least women must be represented at all decision-making levels as equal development partners. In order to ensure that, many women are nowadays indulging in associative life as defenders of women's rights. Such a step would significantly contribute to put an end to the injustice perpetrated against women who represent more than half of the world population. For instance, a fair and equal representation of women would secure more moral and financial accountability in public and private resources management, poverty alleviation or eradication, and eventually propel a holistic development. But by probably drawing on his family background or the advert effects of industrialization in Great Britain, Dickens, in his oeuvres has depicted women's idiosyncrasy. Any way, if industrialization should undergo a second birth or renaissance, there should be more room for it to cater for, and protect women due to their multifaceted roles of paramount importance in the overall development process.

\section{REFERENCES}

[1] Eliot, G. Silas Marner, Longman Group Limited: U.K, 1984

[2] Eliot, G.: The Mill on the Floss, Penguin Popular Classic: London, 1994, Preface

[3] Dickens, Ch. Hard Times, England : Penguin Classics 1995

[4] Dickens, Ch. Great Expectations, London : Longman,

[5] Keating P.J., The working Class in Victorian Fiction, London: Routledge, 1971

[6] Gaskell, E. Mary Barton, Penguin Classics, Edited by Stephen Gill, 2003.

[7] Kottak Ph.C. Anthropology: The Exploration of Human Diversity, New York: Mcgraw-Hill, Inc., 1991. 
Exploring Women's Identity in Selected Charles Dickens's Works: A re-visitation from a Contemporary African Perspective

[8] Koumakpaï, T. "The Moral Growth of George Eliot's Heroines: A Critical Study". In Liberal Forum, 96 (3) 2000

[9] Koussouhon, L. \& Dossoumou, A. "Exploring Ideational Meta-function in Helon Habila's Oil on Water: A re-evaluation and redefinition of African Women's Personality and Identity through Literature". In International Journal of Applied Linguistics and English Literature Vol.4, No. 5, pp 129-136, 2015.

[10] Toyne, A. An English-Reader's History of England, London: Oxford University Press, 1971.

[11] Tossou, O. Femme, Cotonou : Plume Soleil, 2013.

[12] North and South, The Penguin English Library, Edited by Dorothy Collin,

[13] 1996. Ruth ed. Angus Easson. London: Penguin, 2004

[14] Wives and Daughters: An Every-Day Story. 1864-66. Ed. and intro. Angus Easson. Oxford: Oxford UP, 1987.

[15] Rodney, W. (Introduction by Vincent Harding), How Europe Underdeveloped Africa, Panaf Publishing Abuja, Lagos, Pretoria, 2009,

Website

[16] http://www.un.org/africarenewal/magazine/july-2005/african-women-battle-equality

[17] http://www.afdb.org/fileadmin/uploads/afdb/Documents/Knowledge/25040341-FR-DRAFTDEJENE.9-15-07DOC.PDF

\section{AUTHOR'S BIOGRAPHY}

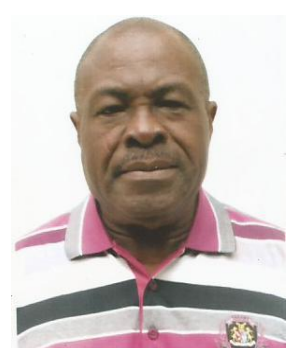

Taofiki KOUMAKPAÏ, holds two Doctorate degrees- one from the University of Grenoble and one (Thèse d'Etat) from the University of Abomey-Calavi. He is presently Full Professor (CAMES) of British Literature and Civilization. Prof. Koumakpaï was the former Head of Department of English Studies Head of Department of English Studies, Faculty of Arts and Humanities (F.L.A.S.H.) of the University of Abomey-Calavi (UAC). His career of scholar has propelled him to the position of Director of Scholarships Aid. Besides, Professor KOUMAKPAÏ has held for ten years, the position of Permanent Secretary of the President of Economic and Social Council in Benin. Prof. Koumakpaï is an English-French-English translator, therefore a bilingual scholar who has profusely published articles both in French and English in national as well as international journals. 